\title{
The Potential of Gamma-Valerolactone (GVL) Production from Oil Palm Biomass
}

Man Kee Lam* and Yoshimitshu Uemura

Chemical Engineering Department, Universiti Teknologi Petronas, Malaysia

Worldwide concern on the heavy dependence of fossil fuel has further accelerated the development of renewable biofuel. Besides the production of biodiesel, bioethanol, biomethane and biohydrogen from renewable sources, gamma-valerolactone (GVL) appeared as another potential green fuel that can be derived from biomass. GVL is a colorless liquid with chemical formula of $\mathrm{C}_{5} \mathrm{H}_{8} \mathrm{O}_{2}$ [1]. It is stable at normal condition, has high boiling point and low toxicity [2]. In addition, GVL also recognized as an excellent solvent in biomass conversion, in which it can enhances saccharification process by completely dissolving the biomass including lignin fraction [3]. Recently, GVL has been suggested as a potential liquid fuel due to its similar combustion energy to ethanol $(29.7 \mathrm{MJ} / \mathrm{kg})$. In fact, GVL can be further processed to produce other chemical compounds and fuel additive, such as butene, pentanoic acid, 2-methyltetrahydrofuran (MTHF), 1,4 pentanediol and 5-nanonene [2].

GVL can be derived from cellulose materials via four important steps (Figure 1): (1) hydrolysis of cellulose to glucose, (2) dehydration of glucose to hydroxymethylfurfural (HMF), (3) hydration of HMF to levulinic acid and, (4) hydrogenation of levulinic acid (LA) to GVL $[2,4]$. Current research on GVL is mainly focused on the screening of hydrogenation catalyst to convert LA to GVL, and it is reported that catalyst containing $\mathrm{Ru}$ exhibited the most promising results [5-7]. Development of heterogeneous catalyst for the hydrogenation reaction is the next effort to truly realize commercial-scale production of GVL. This is predominantly due to easy separation of the heterogeneous catalyst from GVL liquid phase and thus, promoting economical pathway to manufacture GVL [4].

Since lignocellulosic biomass is consisting of a major portion of cellulose and hemicellulose, it has been identified as the best feedstock for GVL production. In conjunction, oil palm biomass is one of the most abundant biomass available in South-East Asia, specifically in Malaysia, Indonesia and Thailand [8]. Apparently, palm oil contributed 38.5 million tonnes or $25 \%$ share of the world's oils and fats markets, which is the largest portion among other edible oil sources, such as soybean, rapeseed and sunflower [9]. However, the expansion of oil palm industries has further raised the concerns of environmentalist

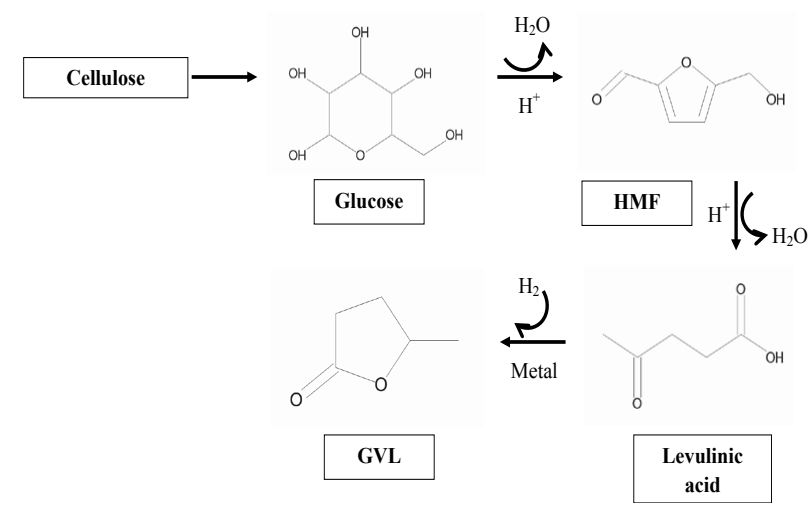

Figure 1: Production of GVL from cellulose material (modified from [2]). and public due to the increasing generation of oil palm biomass and residues (e.g. empty fruit bunches, palm kernel shells, trunks, fronds and mesocarp fibers) [10]. It is projected that 21.6 tonnes of oil palm biomass can be generated annually per hectare of land or accounted for more than 100 million tonnes of biomass production globally [10]. For example, in Malaysia, the palm oil agriculture industry has contributed $85.5 \%$ of the total biomass production in the country [11].

Oil palm biomass generally consisting of cellulose, hemicellulose and lignin, and compositions are depending on the plant species. Nevertheless, relative high composition of cellulose (30-38\%) and hemicellulose (23-40\%) in oil palm biomass has made it a feasible source of GVL production [10]. In these recent years, hydrolysis of oil palm biomass to glucose for bioethanol production has been extensively carried out. From a few recent studies, high glucose yield can be attained from oil palm biomass via different pre-treatment and hydrolysis methods, such as alkaline, acid and enzymatic [12-15]. Hence, further upgrading the glucose to LA and GVL is seems possible and therefore, intensifies the bio-refinery development of oil palm industry.

In the near future, it is expected that GVL production from oil palm biomass will diversify the renewable biofuel markets, as well as creating a sustainable platform for wealth generation and environmental protection. However, more researches are still heavily required to identify the bottlenecks of GVL production from oil palm biomass and its techno-economic feasibility. This includes some technical issues that needed to be further addressed, such as recalcitrant effect of oil palm biomass that hinder the hydrolysis process, conversion efficiency of LA to GVL and potential recycling use of hydrogenation catalyst.

\section{References}

1. Yan K, Lafleur T, Jarvis C, Wu G (2014) Clean and selective production of $\mathrm{Y}$-valerolactone from biomass-derived levulinic acid catalyzed by recyclable pd nanoparticle catalyst. J Cleaner Prod 72: 230-232.

2. Alonso DM, Wettstein SG, Dumesic JA (2013) Gamma-valerolactone, a sustainable platform molecule derived from lignocellulosic biomass. Green Chem 15: 584-595.

3. Alonso DM, Wettstein SG, Mellmer MA, Gurbuz El, Dumesic JA (2013) Integrated conversion of hemicellulose and cellulose from lignocellulosic biomass. Energy Environ Sci 6: 76-80.

4. Wright WR, Palkovits R (2012) Development of heterogeneous catalysts for the conversion of levulinic acid to $\mathrm{Y}$-valerolactone. ChemSusChem 5: 1657-1667.

*Corresponding author: Man Kee Lam, Chemical Engineering Department Universiti Teknologi Petronas, 32610 Bandar Seri Iskandar, Perak, Malaysia, Tel: +605-368 7548; Email: lam.mankee@petronas.com.my

Received May 04, 2015; Accepted May 06, 2015; Published May 11, 2015

Citation: Lam MK, Uemura Y (2015) The Potential of Gamma-Valerolactone (GVL) Production from Oil Palm Biomass. J Adv Chem Eng 5: e105. doi:10.4172/20904568.1000e105

Copyright: @ 2015 Lam MK et al. This is an open-access article distributed under the terms of the Creative Commons Attribution License, which permits unrestricted use, distribution, and reproduction in any medium, provided the original author and source are credited. 
Citation: Lam MK, Uemura Y (2015) The Potential of Gamma-Valerolactone (GVL) Production from Oil Palm Biomass. J Adv Chem Eng 5: e105. doi:10.4172/2090-4568.1000e105

Page 2 of 2

5. Mehdi H, Fabos V, Tuba R, Bodor A, Mika LT, et al. (2008) Integration of homogeneous and heterogeneous catalytic processes for a multi-step conversion of biomass: From sucrose to levulinic acid, $\mathrm{Y}$-valerolactone, 1,4-pentanediol, 2-methyl-tetrahydrofuran, and alkanes. Top Catal 48: 49-54.

6. Deng L, Li J, Lai DM, Fu Y, Guo QX (2009) Catalytic conversion of biomassderived carbohydrates into gamma-valerolactone without using an external $\mathrm{H} 2$ supply. Angew Chem Int Ed Engl 48: 6529-6532.

7. Yan ZP, Lin L, Liu S (2009) Synthesis of $y$-valerolactone by hydrogenation of biomass- derivedlevulinic acid over ru/c catalyst. Energy Fuels 23: 3853-3858.

8. Shuit SH, Tan KT, Lee KT, Kamaruddin AH (2009) Oil palm biomass as a sustainable energy source: A malaysian case study. Energy 34: 1225-1235.

9. Lam MK, Tan KT, Lee KT, Mohamed AR (2009) Malaysian palm oil: Surviving the food versus fuel dispute for a sustainable future. Renewable Sustainable Energy Rev 13: 1456-1464
10. Kelly-Yong TL, Lee KT, Mohamed AR, Bhatia S (2007) Potential of hydrogen from oil palm biomass as a source of renewable energy worldwide. Energy Policy 35: 5692-5701.

11. Umar MS, Jennings $P$, Urmee $T$ (2013) Strengthening the palm oil biomass renewable energy industry in malaysia. Renewable Energy 60: 107-115.

12. Hassan O, Ling TP, Maskat MY, Illias RM, Badri K, et al. (2013) Optimization of pretreatments for the hydrolysis of oil palm empty fruit bunch fiber (efbf) using enzyme mixtures. Biomass Bioenergy 56: 137-146.

13. Tan HT, Lee KT (2012) Understanding the impact of ionic liquid pretreatment on biomass and enzymatic hydrolysis. Chem Eng J 183: 448-458.

14. Yunus R, Salleh SF, Abdullah N, Biak DR (2010) Effect of ultrasonic pretreatment on low temperature acid hydrolysis of oil palm empty fruit bunch. Bioresour Technol 101: 9792-9796.

15. Sukri SSM, Rahman RA, Md Illias R, Yaakob H (2014) Optimization of alkaline pretreatment conditions of oil palm fronds in improving the lignocelluloses contents for reducing sugar production. Rom Biotechnol Lett 19: 9006-9018. 